\title{
Cultural Heritage and Architecture: A Case of Ojude Oba in Ijebu Ode South-West, Nigeria
}

\author{
ANIFOWOSE Titilayo, \\ Department of architecture, Faculty of Environmental Studies, University of Lagos Akoka, Nigeria
}

\begin{abstract}
Cultural heritage and architecture in this study functions as intuition that reflects how people distinguish themselves and comprehend their environment. Ijebu ode people has rich cultural heritages infused in her language, songs, festivals, folktales, lore, chants, history and literature. Festivals are very significant as they bring people together of a particular society, to create cultural cognizance and avenue. Ijebu people celebrate festivals unique to their culture and customs. Ojude Oba festival is celebrated by the Ijebus who are famous for both their enterprise and affluence. This study examines cultural heritage and architecture a case study of Ojude oba in Ijebu Ode South-West Nigeria. Ojude Oba festival constitutes a major commercial activity that conveys economic integration and development of the Ijebu communities. Data was sourced from field work, focus group discussions, oral interviews and relevant literature. This study showed how cultural heritage influences people's sense of identity, loyalties and behavior. Memory institutions [archives, libraries, museums, schools, and historic sites] have a responsibility for preserving and interpreting the cultural record, so there are practical reasons to study cultural heritage. This research concluded with how cultural heritage called ojude-oba in Ijebu-Ode affects individuals' self-identity, self-esteem, and relationships with others.
\end{abstract}

Keywords: Cultural heritage, Festival, Identity, Tradition, Cultural beliefs.

\section{INTRODUCTION}

Culture is made up of customs, traditions, beliefs, behaviour, dress, festivals, works of art and craft, approach to life among others, which varies from society to society which submits that cultural values are relative [1]. Every member of a community is expected to show support for the occasion by joining the crowd or by partaking of the rites. Yoruba annual festivals, such as Ifa festival in Abeokuta, Sango festival in Oyo, Ogun festival in Ondo and Ijesa land, Ojude oba festival in Ijebu land, gelede festival in Yewa land, Oro festival, Egungun festival are very important events. Festivals are occasions for reunion of the people with their gods and for renewal of religious and social values. Religion is the focal point of Yoruba culture [2]. Mostly festivals, religious activities play a vital role and contestant in a festival classifies himself with the sacred time through ritualized-symbol of the events that inform man about his identity [3]. Contribution in the rites of local traditional deities accepted in such a community becomes a strong means of identity establishment and yields a mutual mystical consciousness [4]. The religious ethics, traditions and ideas are evidently stated through the songs the devotees sing during the festivals. Oyetade affirms that Yoruba religious festivals have welfare objectives, during a festival the divinity is conciliated to in order that the devotees and the entire community may enjoy another year of protection, plenty and happiness [5].

\section{LITERATURE REVIEW}

Festival periods are luminal times when people come together as a group, renew their relationships and fortify their cohesion. They are sort of sacred times when people are free from the social constraints of normal life in an intense form of social communion and solidarity. Adedimeji stated that culture symbolizes the people's means of life, norms, values, morals, ethos, ethics, and customs. Adedimeji acknowledged diverse principles of cultural heritage in any society as follows: Culture functions as intuition that reflects how people distinguish themselves and understand their environment. Culture acts as a spring of motivation. How people react to as incentives or disincentives for positive designs of behaviour is occurrence that is influenced by culture. Culture defines production and consumption attitude of people. The Igbo tribe in Nigeria is noted for their daring entrepreneurship traits [6]. A larger percentage of what is "made in Nigeria" is produced by the Igbos. While cultures may imbue productivity, other cultures may resolve to consumerism. Attitudes to education are also culturally determined. Culture and identity form and give positive meanings to local places and urban space as a whole [7]. Built environment and culture are closely 
related to each other. In a certain way, the design of the built environment carries and promotes culture. The linking element between the environment and culture is the urban squares [8]. Cultural activities and events are a main purpose for gathering people; they are the link between the space and people.

Cultural heritage is considered as a combination of several elements, which are: human processes, activities, and urban elements [9]. Tangible cultural heritages include man's physical artistic products which can be touched and seen in architecture/buildings, defensive walls and ditches, crafts, tools, ivory, cowries, paintings, textiles, pestles, mortars, iron furnaces, knives, food, wooden objects, tombs \& grave goods, temples, dresses, pottery \& potsherd pavements, monuments, books, works of art, and among other artifacts. "Artifacts are objects/features made used by man in an attempt to cope with the challenges and problems of social and natural conditions. It is important to confirm that man cannot live without the creation and use of artifacts" [10]. Cultural heritages was partly cut off due to unsolicited arrival of colonialism in Nigeria. Many critics have pointed out that the use of culture to improve a range of social and economic goals is most apparent in cities [11] and urban arts festivals have grew to a greater degree than any other type [12]. In the past 20 years, numerous arts festivals have been presented in the interest of revitalizing urban economies, regenerating entire cities or city districts and introducing or repositioning cities on the ever more competitive global stage $[13 ; 14]$

Festival stresses a re-presentation of space in order to enable the securing of the festival gaze onto the city to occupy the visitors. Instead of presenting the city as a unitary manifestation we may look at urban practices that define the city [15]. Lefebvre and de Certeau are concerned with the average life, whereas the festivalized city can be seen as existing outside, or perhaps equivalent to everyday. In several cases the city is not a fixed entity but rather becoming transmission, arrangement and recombination of people and things' [16]. In the perspective of festival, this becomes a means for reconfiguring the city space for alternative activities outside the normal realm. The city becomes an experience scape, a 'stylized landscape that is strategically planned, laid out and designed [17]. Ordinary space is transformed into festival space, a 'edged spontaneous play that contrasts repetitive everyday life' [18]. The outwardly carnivalesque attribute of festival is diligently directed: behind the dynamic street sights, the gaze is influenced by investor, societies of local government and an growing service economy, which benefit from the promotion of the festival's playfulness and liminality. Although spaces appear as though spontaneously formed by the company of strangers and the collective experience of performances, the city is also the result of painstaking planning by a city administration that seeks to control the ways in which public spaces change. The city is redefined by the changing vitality and swiftness of purposefully planned festivalized spaces [18].

Mbiti opposes that without festivals and rituals, African life would be dull, "rituals and festivals are religions ways of implementing the values and beliefs of society" [19]. Among the Yoruba, festivals may complement birth, initiation, marriages and funerals. There are also harvest festivals, coronation festivals and so on, but the major religious festivals are those done in honor of some gods as mark of loyalty and to importune blessings from the deity. Yoruba People have different cultural heritage that can be celebrated as festivals unique to their culture and customs. Festivals serve as a means of community gathering and unity. They are also a way of placing the people at the heart of their culture and social environment. Owusu-Frempon noted that African festivals are "medium of cultural education and inter-generational statement that display an important role in the protection of our cultural heritage, spreading knowledge and our experiences as a people to future generations" [20]. The Ojude Oba festival in Ijebu Ode serve all the above stated functions moreover, play a religious role in the life of the people of the communities.

Festivals and other cultural events are seen as a means to contribute to a positive image of a place, and to create employment opportunities, to further economic growth [21] and entrepreneurial confidence [22]. They are a vehicle for bringing together a range of stakeholders, such as performers, visitors, inhabitants, volunteers, entrepreneurs, and the public sector, and have thus become 'increasingly written into civic cultural policies as both product and framework, designed to attract a wealthy target market and furnish the city with a competitive image' [18]. To organize such events is often part of an official strategy for enhancing the attractiveness of a place [23]. As a result of a general culturalization of the Yoruba town of Ijebu-Ode is situated to the south-east of Ibadan; it is one of the major towns of Ogun State [and indeed, of the old Western Region of Nigeria].

\section{CONTEXT OF THE STUDY}

The selected case study is Ijebu-Ode in Awujale palace square, Ijebu-Ode town in Ogun state.

Ijebu-Ode is located in latitude $6.82^{\prime} \mathrm{N}$ and longitude $3.92^{\prime} \mathrm{E}$ of South central part of Ogun state. Ijebu-Ode is the Local Government headquarters of Ijebu-Ode Ogun State, Nigeria. According to National Population Commission [2006] Census, population of Ijebu-Ode is 209,170 out of Ogun state 3,751,140. Awujale palace is the administrative hub of Ijebu-Ode where 
Ijebu people are govern traditionally. The palace is also the seat of Ijebu. Ijebu Ode is the Ijebu province, which occupy southcentral Western Nigeria. It is the headquarters of the Ijebu and is surrounded by a ring of smaller towns having between 2,000 and 5,000 residents each. The Ijebus have their own dialect, culture and established identity. The people of Ijebu Ode sometimes regard themselves as the "great Ijebus" and see other areas as rural areas. Figure 1 below shows the map of Ogun state where Ijebu-Ode is located.

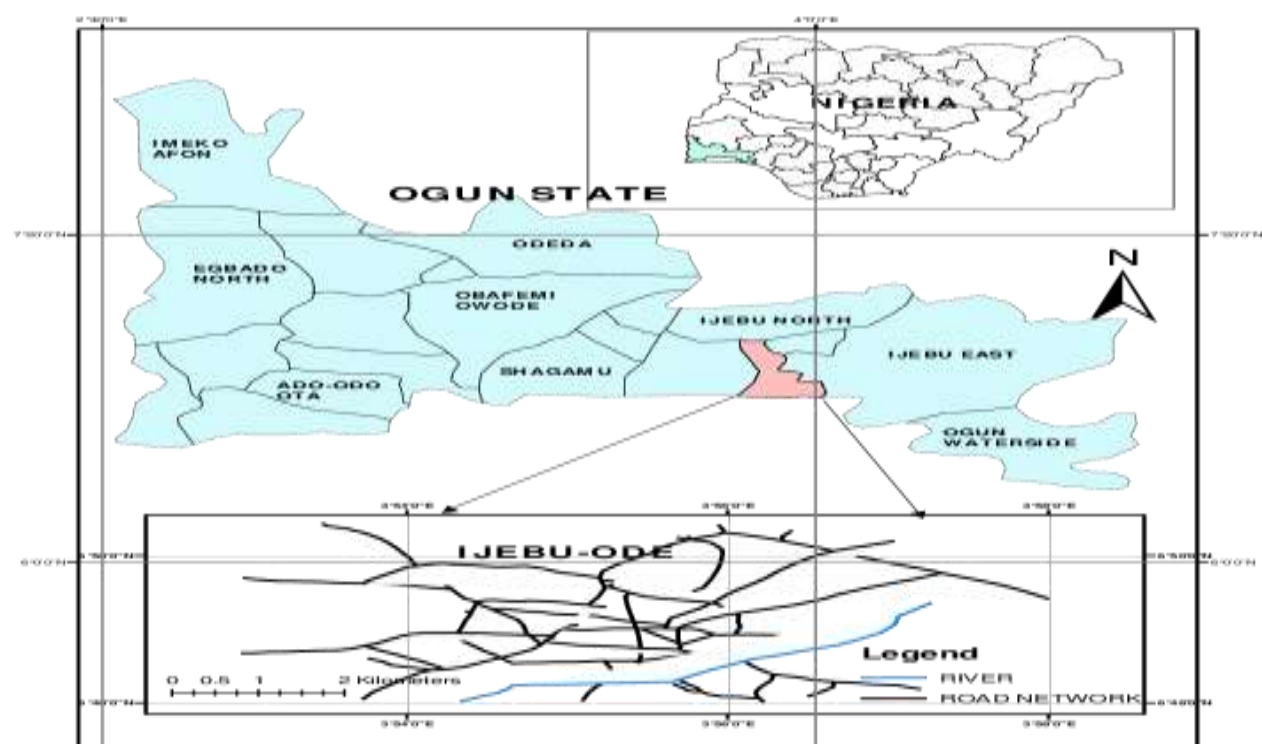

FIGURE 1: MAP OF OGUN STATE IN NIGERIA SHOWING IJEBU-ODE LOCATION

\section{METHODOLOGY}

Qualitative research method was adopted since the essence is to investigate the cultural heritage and architecture. A study of the related and recent literature on subject matter, focus group discussions, observation and unstructured interview was conducted with the opinion leaders. History and characteristics of Ojude-Oba was descriptively obtained from the opinion leaders. Data was analyzed with place and sustainable theories.

\section{RESULTS AND DISCUSSION}

The rhythm of human civilisations has always been disrupted by moments when collectively, people at local, national and international levels celebrate festivals. The role of cultural practices and knowledge plays in the conveying and preservation of cultural heritage cannot be over stressed. It is a veritable medium by which Africans transfer their cultural heritage from one generation to the other. Due to the flexibility of the medium of exchange of cultural heritage, it stands the risk of being lost or forgotten. This situation therefore, made preservation and conservation of cultural heritage a very important task to researchers in order to ascertain forwards transfer of these traditions to unborn generations.

\subsection{ORIGIN OF IJEBU PEOPLE}

The Ijebus are located in the south-central part of Southwestern Nigeria, regarded as Yorubaland. Ijebuland is bordered in the north by Ibadan, in the east by Ondo and Okitipupa, and the west by Egbaland. The southern border is close to the sea with the coastlines of Epe, Ibeju-Lekki, and Ikorodu. Although the people have always regarded themselves as one, modern Nigeria political division has placed three Ijebu-speaking local government council areas [Epe, Ibeju-Lekki, and Ikorodu] in Lagos State, whereas the larger part of Ijebuland is in Ogun. During focus group discussions of opinion leaders and traditional historian in Ijebu Ode claimed that they migrated to their present place from a region in Sudan called "Owodaiye," corrupted to "Wadai." Validations given in support of the claim that the Ijebus migrated to Nigeria from Sudan are as follows: the Sudanese tribal marks that are similar to the Ijebus three tribal vertical marks to show a true indigene of the region; the familiarity of the original Arabic dialect spoken in the border of South Sudan and Ethiopia to the Ijebu dialect; names such as Esiwu, Saba, and Meleki [Menelik] found among the Ijebus and the Southern Sudanese people; and the musical flute that was used in the former coronation of the Awujales, that is still in vogue among the Ethiopian and Southern Sudanese people. Some Ijebu people also claimed to come to their present place from Ife like other Yoruba in their oral tradition. 
Ijebu customs claim that Ijebu-ode is founded by three brothers: Olu iwa, Ajebu and Olode who came from Ile-Ife and Ijebu Ode was formed from the two of them Ajebu and Olode. The first Ijebu movement was led by a man named Olu-iwa, accompanied by two warriors Ajebu and Olode. The Agemo and Osugbo play important political and judicial roles. The most noticeable tradition is the Awujaleship. The Awujale is the office of the king of Ijebuland. The Awujale's role is to provide traditional leadership in connection with various districts. It is in Ijebu Ode that the Ojude Oba [the outlook of the king] festival is held. Over 70\% of Ijebu-Ode is given over to residential buildings. Awujale palace is located at the center of Ijebu-Ode. The location of Awujale palace is based on Yoruba town urban formation where the town evolved from the king's palace. King's market in Ijebu-Ode is called Odo-Egbo Market which is close to Awujale's palace. Other markets namely Ita Osun and Ita Ale, a night market. [The wordita, in the Ijebu dialect, means "market"].

Most markets in the town are held on a 5-day rotational system e.g. Ita Osun. There are various industrial concerns scattered all over the town and its environs, such as a quarrying industry [a partnership between the Nigerian government and Switzerland] at Oke-Eri, a bottle-top manufacturing industry [Crown Industries Ltd.], a private rubber-processing venture producing tyres, mattresses and pillows [Odutola Tyres \& Retreads/ Tola Foam], and the Wadai Shoe Factory, among others. The "service industry" consists of a General Post Office, fire and electricity services, chemists and supermarkets. On the social side are schools - both primary and secondary - hospitals and clinics, churches and mosques, a cinema, a public library and Town Hall. The administrative sector is made up of several ministries [e.g. that of Agriculture and Natural Resources], a High Court [and several lesser ones], at least one Police Station, a Tax Office, a Licensing Office, a Town Planning Authority and Local Government affairs office.

\subsection{OJUDE OBA FESTIVAL IN IJEBU-ODE}

One of the most popular festivals peculiar to the Ijebu-speaking community, is Ojude Oba [the outlook of the king] festival that takes place in Ijebu-Ode annually. Ojude Oba festival is celebrated by the Ijebus who are famous for both their creativity and wealth. During the festival celebrations some unique features of the community are displayed like their fashion sense, music, costumes, food etc. Ojude Oba plays a religious and social role in the life of the people of the community. The festival constitutes a major viable activity that brings about economic combination and enlargement of Ijebu community. Ojude Oba festival is not just for its performing value, but an exhibition of Ijebu cultural, socio-economic, and spiritual values. Historically Ojude Oba could be translated as "majestic outing." The Ojude Oba festival in Ijebu Ode is known to the Ijebus as a main festival that brings people together. The native age groups [regberegbe], indigenes, their friends and associates from far and near flock the palace of Awujale of Ijebuland for the carnival-like celebration. The festival is celebrated annually on the third day after Id-El-Kabir. Ojude Oba is one of the most dazzling cultural and spiritual festivals in Ijebuland and in Ogun State in general. This is a festival that has traditional, cultural, religious, social, and military significance. It has been celebrated for more than 100 years. According to verbal antique accounts, the festival began when Balogun Kuku, one of the leading personalities in the community, became Islam.

Balogun gathered his friends, families and well-wishers to pay tribute to the king for giving them the opportunity to practice their religion peaceably. They prayed for the monarch to enjoy a long life, good health, and for the progress and prosperity of Ijebuland. Subsequently what began as a visit has developed and assume the status of a flagship cultural festival. The Festival the glamor and colors associated with the festival rank among the most celebrated cultural festivals in Nigeria. Ijebu sons and daughters, Muslim and non-Muslim always look forward to this annual event. It is an ancient tradition. The ceremony takes place every year on the third day of eid-l-adha, Muslims and non-Muslims go to the Awujale palace singing and dancing with the primary chiefs of the town and riding on horses to pay homage to the Awujale. The uniqueness of this event is that Awujale sits on the throne during the ceremony to receive his people. Diverse age groups in special dresses dance around the town. However the festival began as purely Islamic affair, it has over the years acquired new meaning as it now clinches traits of local tradition. The festival begins with prayers by the Imam of Ijebuland, followed by the National Anthem, Ogun state Anthem, Awujale Anthem and finally the lineage praise of the Ijebus. The Awujale anthem goes thus: Kaabiyesi o [2ce] Alaiye Oba wa, K'adepel'ori o kibatape lese, k'adepel'ori. K'odigbapel'orun, Ki Oba petiti, Ki ijobatuwalara, kaabiyesi o. Oba waoninu re. Kaabiyesi o [2ce]. Next the anthems and lineage praise, the pageant of different ages in the community known as regberegbe begins.

\subsection{Different Age groups in Ojude-Oba Festival Ijebu-Ode}

The age grade societies were established in Ijebuland in 18th century. Wompari is the general name given to all the age grade societies. Some of the age grades include Egbe Gbobaniyi male and female that was established in 1962-1964, Egbe Bobagunte male and female was established 1956-1958, Akile of Ijebu 1959-1961, Mafowoku, Egbe Arobayo male and female, Egbe Jagunmolu 1965-1967, Egbe Bobakeye, and Egbe Bobagbimo. All the age grades present their special gift to the king as they parade. The Wompari is a distinctive society, designed to exert the society into age groups; male and female and for conveying growth and improvement to the community. Most of these individuals comprise important dignitaries in their life endeavor. The 
stated groups dance before the king one after the other and each group is expected to dressed in the latest fashion. During the 1day event are the radiant tributes of a festival that is alert to social trends while retaining the tradition of having different age groups to entertain and renew their commitment to the traditional ruler. It is usually a dance but more notably a dance with meaning. Each group displays at the spacious lawn that separates the king and his guests from the crowd which makes the festival an inspiring experience.

Ojude Oba festival has enough visual pleasantries for every viewers. Several of the fascinations are the beauty of a group of people in the same age group coming together in service of their homeland. Many of the groups' names are related to the king such as Obafuwaji, Bobakeye, Gbobayo, Gbobaniyi and Gbobalaye. Each of these groups has its distinctiveness either in the manner of appearance, style of dressing, or dance pattern. The Gbobaniyi comprises young middle-age men and ex- governor Gbenga Daniel was its patron in year 2004. The mock war is one of the curricula by the chieftain families in the Ojude Oba festival. Chieftain appearance known by dressing in rich traditional AsoOke clothes. They all hold walking sticks and dance like conquerors. The Bobagbimo, exact to the group's name, always appear in learned and cerebral attire. The group has little of dance and pleasantries but more of smiles, nods, and prayers. Happiness and dance are the symbols of the all-female Gbobaleye, which has the Waka Music Superstar, Queen Salawa Abeni as one of its prominent members. The parade of the Baloguns and Eleshins is usually the most colorful and amazing happening of the festival. Balogun or an Eleshin is a direct descendant of the war heroes who gained notable victories for the Ijebu during the inter-ethnic Yoruba wars in the pre-colonial history of Nigeria. It is commonly believed that it was at Ojude Oba that the families of the war heroes led by the reigning Balogun and deputies displayed their riding prowess by simulating mock battle shows and displays. It is always a performance to behold when each Balogun and Eleshin family takes its turn to pay homage to the king amid martial music, jubilation, and hilarity of an estimated crowd of over one million both at the palace square and through the town including participants, visitors, and tourists. This was what made Oba Sikiru Kayode Adetona to describe the Ojude Oba day as the Ijebus' national day.

\subsection{Ojude-Oba an Inventive Festival of Beauty}

Inventive Beauty of the Ojude Oba Festival Art plays a significant role in the festival. It is one of the reasons people from completely different cultural settings find the festival very interesting. While looking at the artistic beauty of Ojude Oba, we took into consideration the manner of dressing of the different age groups, music and musical instruments, the design on the horses of the Balogun families, the pattern of the banners and fans used in the ceremony, and so on. Dressing In many Yoruba societies, dresses or the traditional robes play important roles in ceremonies. It is one of the ways to display one's economic status within the society. During Ojude Oba, the age grades try to beat one another through the kind of dress they wear. Therefore, it is not surprising when we see different age grades dressed expensive kinds of cloth known to the people of the community. In the age grade that comprises men and women, all are supposed to dress in the same pattern of cloth. The sheer impact of bulk and color and stripes created by an assemblage of individuals in close proximity, each person robed in identical pattern and hue, is indeed considerable. The attire worn in the previous festival would not be repeated in the next festival. This is to show their economic status and wealth and make a statement that they are doing fine in their age grade. Most often, it is an entirely different dress that would be worn in the next Ojude Oba. The difference would not only be in color but also in style.

Traditionally, the favorite colors of the Yoruba are tan, the rich natural tone of the silk known as sanyan, and blue, ranging from the palest to the deepest blue black obtainable from the indigo dye pots. Reds and an occasional yellow are also traditional preferences. More recently, however, innovations in pattern and hue have come to be prized, so that there is a more varied palette and an increased reliance on commercially manufactured yarns rather than dependence on handspun and locally dyed weaves. This is why today, some age grades would wear agbada [big overall cloth for men], laced with green damask. In one of the previous Ojude Oba festivals, all the age grades wore the same pattern of cloth; the only difference.

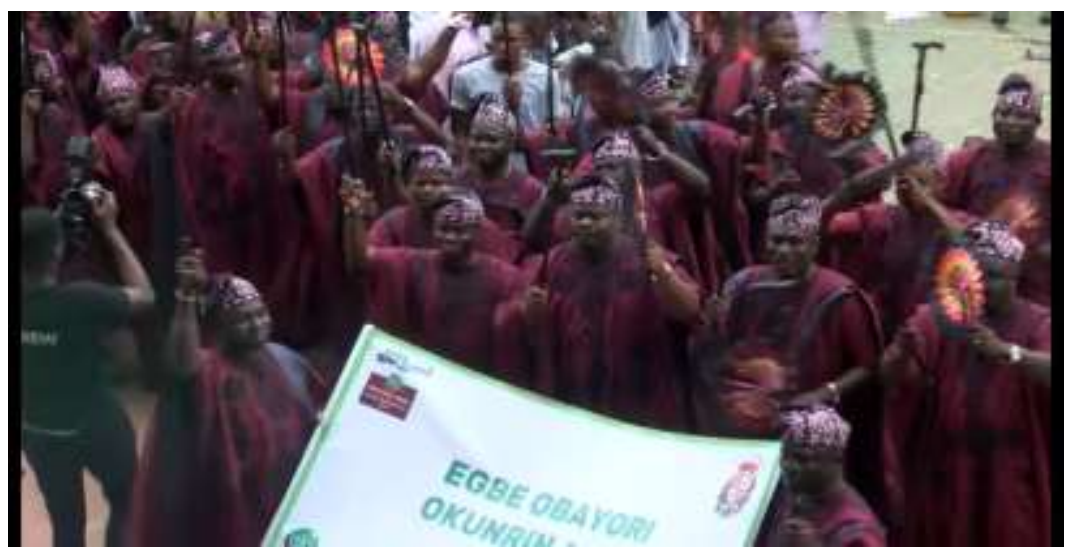

FIGURE 2 SHOWING EGBE OBAYORI OKUNRIN DURING OJUDE-OBA 2019 
Music and musical Instruments is an important part of the Ojude Oba festival and traditional music can be described as music drama. The dramatic aspect of this music is given its highest expression in situations of a ceremonial nature in which music, dance, speech, physical movement, costume, and art objects all combine to constitute a complete performance. In Ojude Oba, all these are combined to the fullest and are part of what makes the festival memorable. Popular musicians within the country as well as those who are from Ijebuland, such as Salawa Abeni and Wasiu Ayinde Marshal among others are always invited to the festival. Musical instruments used during the festival include various types of drums like Agere, Aran/Ipese, Igbin, Bata, Dundun and sèkèrè [a netted bottle gourd that rattles].
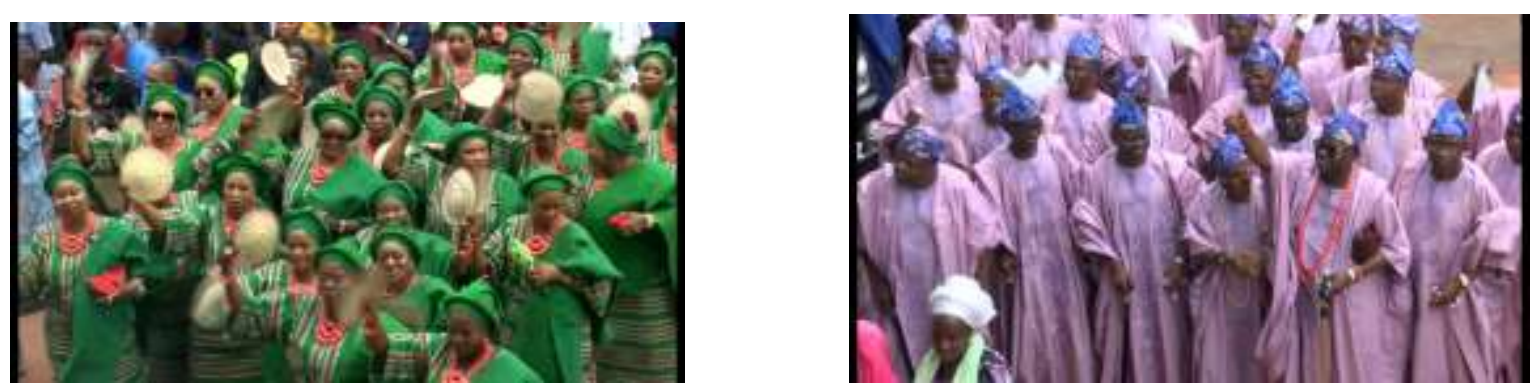

\section{FIGURE 3 SECTIONAL PICTURES OF DIFFERENT AGE GROUPS IN OJUDE-OBA FESTIVAL IN 2019}

The undue decoration of the stallion horses is another interesting thing about the festival. Everything about the horse is decorated, from the head to its hoof. After all the decorations on the horses are done, one finds it difficult. To show skills in riding horses, the horses are made to dance and perform various kinds of tricks like standing on their hind legs and so on. The festival has been used as a means of projecting the image of the Yoruba in general and the Ijebus in particular. Ojude Oba gives the Ijebus an opportunity to renew their allegiance to their king every year they return home from different places within and outside Nigeria. The festival also promotes cultural contact. The festival is usually graced by people from all works of life. Other ethnic groups in Nigeria also participate in the festival whereas people from neighboring countries are not left out. This has promoted peace, tranquility, and harmony, which contribute to socio-economic development and integration. The festival also signifies Yoruba gift for traditional attire. Festival like Ojude Oba is an aspect of African culture imported to Islam. Primarily, the spiritual significance is derived from the origin and aim of the festival. It was started by Muslims during their eid-1-adha, which is considered one of the important events for Muslims. Furthermore, the festival is seen as a continuation of the eid-1-adha celebration by the Muslims in the community, as it is held on the third day of Eid. The festival is not only celebrated by Muslims; Christians as well as people from other faiths join the Muslims in this celebration.

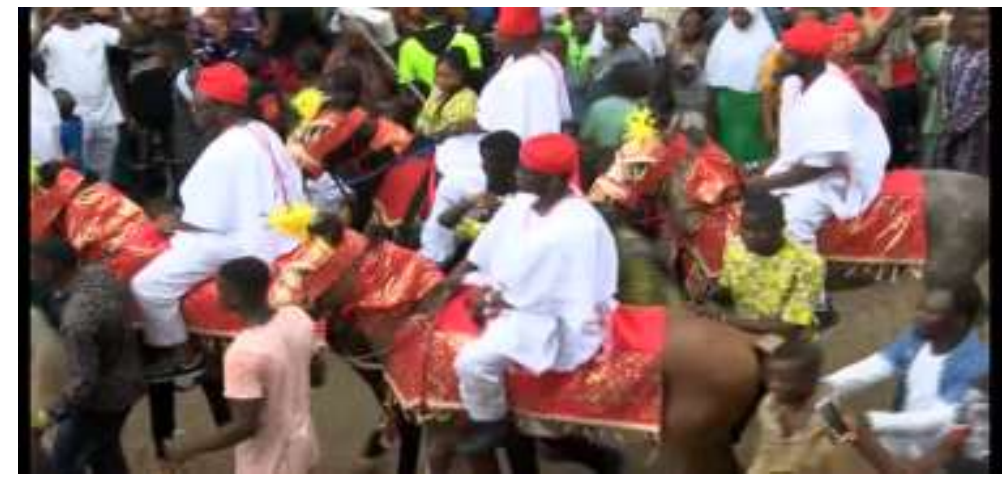

FIGURE 4 SHOWING BALOGUN FAMILY DISPLAYING AFFLUENCE DURING 2019 OJUDE-OBA FESTIVAL

The Ojude Oba festival encourages peaceful co-existence of people of different faiths. The festival serves as an avenue to pray for the king, his members of cabinet, the people, and community as a whole.

\section{CONCLUSION}

This study illustrated, though briefly the cultural beliefs of the Ijebu people with regard to the celebration of the Ojude Oba festival. The festival was noted for its root in the people's belief in honoring the paramount ruler of Ijebuland [Awujale]. It is also a time for the people to display their aesthetic taste in fashion. The artistic and creative talents of the people in terms of dressing, 
drama, music, and oral communication are also put into great use. However, beneath the hustle and bustle and sparked display of colors of this traditional festival, one can discern its attendant socio-cultural significance. Through this festival, the people are not just entertained but the religious and cultural values find an outlet too. In addition, it is also the time most Ijebu people come home to celebrate and reconnect to their roots, reflecting the religious, social, and cultural responsiveness on the part of the people. It is essential to preserve cultural heritage and places in a manner that both sustain their attraction to visitors and the beliefs for which they were preserved. Hence, a policy should be developed to harmonize and bring together all cultural heritage possessions in Nigeria in order to efficiently preserve and conserve the features for posterity. People getting a practical experience of the people's customs, their way of life and their belief systems. The paper is, thus, an attempt to bring to forefront the social significance of religious festivals.

\section{REFERENCES}

1 Edo V.O [2005]"Concepts of Culture and Civilization" in Oguntomisin G.O and Edo V.O [Eds] African Culture and Civilization, Ibadan: GSP, University of Ibadan.

2. Idowu, E.B. [1970]. Olodumare: God in Yoruba belief London: Longman.

3. Famuyiwa, J. [1992]. The Role of Traditional Festivals and modern Festivals of Arts and Culture in the promotion of Cultural education in Nigeria Nigerian Heritage: Journal of the National Commission for Museums and Monuments, Vol. 1

4. Ogungbile, D. [1998]. Islam and Cultural Identity in Nigeria: The Osogbo-Yoruba Orita Ibadan Journal of Religious Studies, Vol. Xxx/1-2, June \& December 1998.

5. Oyelade, T. [2003]. Yoruba Muslims and Cultural Accommodation in Dopamu and Odumuyiwa [Eds] Religion, Science and Culture [Nigerian Association for the Study of Religions [NASR].

6. Adedimeji, M. A. [2009]. Globalization and the survival of the Nigerian cultural and linguistic heritage: The American paradigm. In Adeyanju, D. [Ed.].

7. Madden, D. J. [2012]. Cities Full of Symbols: A Theory of Urban Space and Culture. [P. J. M. Nas, Ed.]. Leiden, NL: Leiden University Press.

8. O'Neil, D. [2006]. What is Culture? Retrieved October 20, 2015, from http://anthro.palomar.edu/culture/culture_1.htm

9. Abdel Tawab, A. G. [2014]. The World Heritage Centrees approaches to the conservation of New Gourna Village, and the assessment of its authenticity and integrity. Alexandria Engineering Journal, 53[3], 691-704. http://doi.org/10.1016/j.aej.2014.01.010

10. Ogundele, S. O. [2014]. Understanding Contemporary Archaeology.Ibadan, John Archers Publishers Limited.

11. Griffiths, R. [2006]. City/culture discourses: Evidence from the competition to select the European Capital of Culture 2008. European Planning Studies, 14[4], 415-430.

12. Pejovic, K. [2009]. Urban arts festivals: A mark on regions. In A.M. Autissier [Ed.], The Europe of festivals: From Zagreb to Edinburgh, interesting viewpoints ... [63-73]. Toulouse/Paris: Edition de l'attribut and Culture Europe International.

13. Shin, H. [2004]. Cultural festivals and regional identities in South Korea. Environment and Planning D: Society and Space, 22, 619-632.

14. Yardimci, S. [2007]. Festivalising difference: Privatisation of culture and symbolic exclusion in Istanbul [EUI Working Papers RSCAS 2007/35]. Florence: EUI.

15. Certeau, de, M. [1984] the practice of everyday life, University of California Press, London, Berkeley

16. Crang M [2001] Rhythms of the City. In: May J and Thrift N [ed.] Timespace. Geographies of Temporality. London: Routledge, 187-207.

17. O'Dell T [2005] Experiencescapes: Blurring Borders and Testing Connections. In: O’Dell T and Billing P [Eds] Experiencescapes: Tourism, Culture and Economy. Copenhagen: Copenhagen Business School Press, 11-33.

18. Jamieson K [2004] the Festival Gaze and its Boundaries. Space \& Culture 7/1: 64-75.

19. Mbiti J.S., Introduction to African Religion, Norfolk: Heinemann, 1991 
International Journal of Advances in Scientific Research and Engineering [ijasre], Vol 6 [5], May-2020

20. Owusu-Frempong, Y. [2005]. Afrocentricity, the Adae festival of the Akan, African American festivals, and intergenerational communication. Journal of Black Studies, 35, 730-750.

21. Herrero LC, Sanz A, Devesa M, Bedate A, and Del Barrio MJ [2007] Economic Impact and Social Performance of Cultural Macrofestivals. In: Richards G [ed] Cultural Tourism. Global and Local Perspectives. Binghamton: The Haworth Hospitality Press, 303-328.

22. Richards, G. [2007]. Culture and authenticity in a traditional event: The views of producers, residents and visitors in Barcelona. Event Management, 11, 33-44.

23. Yeoman I, Robertson M, Ali-Knight J, Drummond S, and McMahon-Beattie U [eds] [2004] Festival and Events Management. An International

24. Smith, M. [2005]. Tourism, culture and regeneration: Differentiation through creativity. In Swarbrooke, J. Smith, M. and L. Onderwater [Eds.], Tourism, creativity and development.Atlas Reflections 2005 [pp. 23-38]. Arnhem: Atlas.

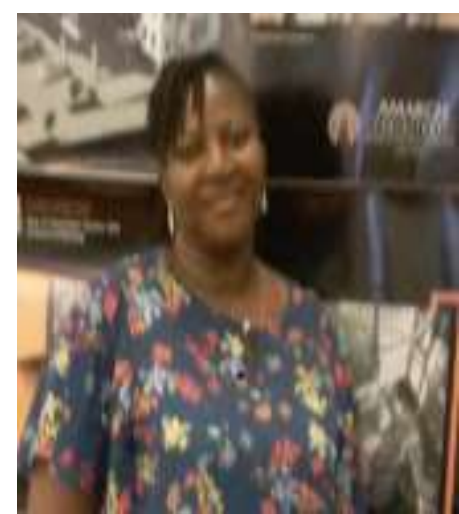

\section{AUTHOR'S PROFILE}

Anifowose Titilayo received Bachelor and Master's degree in architecture from Abia state university, Uturu in 2003 and 2006 respectively. She practiced in construction industry for many years before joining Bell University of Technology in Ota, Ogun state Nigeria in 2020. She teaches research methodology in department of architecture Bell University of Technology Ota. Anifowose Titilayo is doing her PhD in University of Lagos Akoka where her focus is in placemaking [city branding through urban morphology]. She is a member of international society of city and regional planners [ISOCARP]. Recently, her research involves place-making and experience design with socio-cultural aspects. 